\title{
LC-MS/MS based 25(OH)D status in a large Southern European outpatient cohort: gender- and age-specific differences
}

\author{
Silvia Giuliani ${ }^{1,2} \cdot$ Verena Barbieri $^{2,3} \cdot$ Angela Maria Di Pierro $^{1,2} \cdot$ Fabio Rossi $^{1} \cdot$ Thomas Widmann $^{4}$. \\ Manuela Lucchiari $^{1,2} \cdot$ Irene Pusceddu $^{1,2} \cdot$ Stefan Pilz $^{5} \cdot$ Barbara Obermayer-Pietsch $^{5} \cdot$ Markus Herrmann $^{1,2,6}$
}

Received: 29 April 2018 / Accepted: 1 August 2018 / Published online: 7 August 2018

(c) The Author(s) 2018

\begin{abstract}
Background Developed countries have a high prevalence of vitamin D deficiency. In previous studies, 25(OH)D was predominantly measured by immunoassays. The present study assessed serum $25(\mathrm{OH}) \mathrm{D}$ in a very large Southern European outpatient cohort by liquid chromatography tandem mass spectrometry (LC-MS/MS).

Materials and methods 74,235 serum 25(OH)D results generated under routine conditions between 2015 and 2016 were extracted from the laboratory information system of the Department of Clinical Pathology at Bolzano Hospital (Italy). In 3801 cases, parathyroid hormone (PTH) was requested in parallel. Serum 25(OH)D was measured by a NIST-972 aligned commercial LC-MS/MS method. The distribution of serum 25(OH)D concentrations in males and females of different age groups, the prevalence of $25(\mathrm{OH}) \mathrm{D}_{2}$ and seasonal variability were studied.

Results The average $25(\mathrm{OH}) \mathrm{D}$ concentration in the entire cohort was $68.6 \mathrm{nmol} / \mathrm{L}(7.5-1880 \mathrm{nmol} / \mathrm{L})$. Females had a $7 \mathrm{nmol} / \mathrm{L}$ higher average $25(\mathrm{OH}) \mathrm{D}$ concentration than males, which increased significantly with age. 37.9 and $28.3 \%$ of males and females, respectively, had a deficient $25(\mathrm{OH}) \mathrm{D}$ concentration of $<50 \mathrm{nmol} / \mathrm{L}$. 620 samples $(0.84 \%)$ had measureable amounts of $25(\mathrm{OH}) \mathrm{D}_{2}$. In samples with a normal PTH, $25(\mathrm{OH}) \mathrm{D}$ was $11 \mathrm{nmol} / \mathrm{L}$ higher than in the entire cohort. Seasonal variation ranged between 20 and $30 \%$ and was most pronounced in young individuals. $25(\mathrm{OH}) \mathrm{D}_{2}$ remained constant throughout the year.

Conclusion Average serum 25(OH)D in South Tyrol is higher than in other parts of Europe. 25(OH)D and PTH show a continuous inverse relationship. Seasonal variation of serum $25(\mathrm{OH}) \mathrm{D}$ is an important aspect in young and middle-aged adults, but becomes less relevant in elderly subjects. $25(\mathrm{OH}) \mathrm{D}_{2}$ is of minor practical importance in South Tyrol.
\end{abstract}

Keywords $25(\mathrm{OH}) \mathrm{D} \cdot \mathrm{PTH} \cdot$ Mass spectrometry $\cdot$ Data mining

\section{Introduction}

Silvia Giuliani and Verena Barbieri contributed equally and should be considered first authors.

Electronic supplementary material The online version of this article (https://doi.org/10.1007/s00394-018-1803-1) contains supplementary material, which is available to authorized users.

Markus Herrmann

markus.herrmann@medunigraz.at

1 Department of Clinical Pathology, District Hospital Bolzano, Bolzano, Italy

2 Interdisciplinary Medical Research Center (IMREST), Bolzano, Italy

339100 Bolzano, Italy
Vitamin D deficiency is a risk factor for osteomalacia, osteoporosis and fractures [1]. Multiple studies have demonstrated that vitamin D deficiency is also associated with an increased risk to develop other diseases, such as cancer [1], diabetes [2, 3], sarcopenia [4], cardiovascular [5] and

4 Department of Oncologic Rehabilitation, Asklepios Clinic Triberg, Triberg, Germany

5 Division of Endocrinology and Diabetology, Department of Internal Medicine, Medical University of Graz, Graz, Austria

6 Clinical Institute for Medical and Chemical Laboratory Diagnostics, Medical University of Graz, Auenbruggerplatz 15/1, 8036 Graz, Austria 
autoimmune disease [6]. The increased awareness of the high prevalence of vitamin D deficiency has triggered an exponential increase in $25(\mathrm{OH}) \mathrm{D}$ testing.

The appropriate interpretation of serum $25(\mathrm{OH}) \mathrm{D}$ results is a matter of ongoing debate. Consequently, the recommended 25(OH)D cut-offs vary between different scientific bodies [7-10]. Age or gender specific cut-offs are not suggested by any guideline although several studies suggest that physiologic $25(\mathrm{OH}) \mathrm{D}$ requirements may vary with age, gender and ethnicity [11-15]. Interpretation of 25(OH) $D$ results is further complicated by a variable accuracy of $25(\mathrm{OH}) \mathrm{D}$ assays and a strong seasonal variability of up to $20 \%$ [16-19]. Automated immunoassays represent the most widely used method in daily practice. However, the analytical performance of these assays varies substantially [16-19]. In particular, they vary in their efficiency to separate $25(\mathrm{OH}) \mathrm{D}$ from its carrier proteins and are often subject to interferences, such as high concentrations of $25(\mathrm{OH}) \mathrm{D}_{2}$ or heterophile antibodies. LC-MS/MS is the most accurate method for the measurement of $25(\mathrm{OH}) \mathrm{D}$, but is mainly used in research laboratories.

Previous studies have shown a high prevalence of vitamin $D$ deficiency in virtually all developed countries around the globe [20]. However, many of these studies have used immunoassays for the measurement of 25(OH)D [20]. Considering the analytical performance of $25(\mathrm{OH}) \mathrm{D}$ immunoassays, the trueness of results from previous epidemiologic studies is questionable.

Meanwhile, a reference method and a standard reference material (NIST SRM 972a) for the measurement of 25(OH) D have been developed [21, 22]. In addition, the Vitamin D Standardization Program (VDSP) has been launched with the goal to improve accuracy and comparability of analytical methods. However, until today, this initiative has only partially resolved the analytical issues of automated $25(\mathrm{OH})$ D immunoassays. Recently, Cashman et al. performed a reanalysis of previously measured samples with a standardized LC-MS/MS method [20]. The results show substantial over- or underestimation of immunoassays. For example, in a German adult survey, the pre-standardization prevalence of $25(\mathrm{OH}) \mathrm{D}$ serum levels $<30 \mathrm{nmol} / \mathrm{L}$ was $25.9 \%$ and decreased to $15.2 \%$ after standardization. In view of the analytical issues of immunoassays and the very low number of studies that have used higher order methods for the quantitation of $25(\mathrm{OH}) \mathrm{D}$, the vitamin D status of most populations is not well described. Moreover, it remains unclear if the cut-off values proposed by various scientific bodies around the globe are applicable when a NIST 972a aligned LC-MS/ MS method is used to measure $25(\mathrm{OH}) \mathrm{D}$.

The present study aimed to describe the $25(\mathrm{OH}) \mathrm{D}$ status in South Tyrol, a mountainous region in the Southern European Alps using a rigorously controlled, NIST 972a aligned LC-MS/MS. In particular, we studied the distribution of serum 25(OH)D concentrations in males and females of different age groups, the prevalence of measurable amounts of $25(\mathrm{OH}) \mathrm{D}_{2}$ and seasonal variability.

\section{Materials and methods}

\section{Study design}

We analyzed retrospectively all serum $25(\mathrm{OH}) \mathrm{D}$ results from outpatients that were generated between January 1, 2015 and December 31, 2016 at the Central Laboratory of Clinical Pathology at the Bolzano Hospital (Italy). Out of 74,235 samples 3801 cases were identified where PTH was requested at the same occasion. Results were used to study the distribution of serum $25(\mathrm{OH}) \mathrm{D}$ concentrations in males and females of different age groups, the prevalence of measurable amounts of $25(\mathrm{OH}) \mathrm{D}_{2}$ and seasonal variability.

All measurements were performed under routine circumstances. Samples were collected in serum tubes with clot activator. As per routine procedure, samples were centrifuged upon arrival in the lab and stored at $4{ }^{\circ} \mathrm{C}$ until measurement. $25(\mathrm{OH}) \mathrm{D}_{3}$ and $25(\mathrm{OH}) \mathrm{D}_{2}$ were quantitated separately. Results from subjects $<18$ years were excluded from the analysis. The study was approved by the local Ethics Committee.

\section{Biochemical analyses}

25(OH)D analyses by LC-MS/MS were performed as part of our routine clinical work with a commercial kit from Recipe (Munich, Germany) that is traceable to the NIST 972a standard reference material. The method is continuously controlled by daily internal and monthly external quality controls provided by the Royal Australian College of Pathologists Australasia Quality Assurance Program (RCPAQAP). Samples were measured on a Shimadzu 8040 LC-MS/MS instrument coupled to a UHPLC system (Nexera, Shimadzu). Sample preparation consisted in protein precipitation with zinc sulfate, the addition of internal standard $\left(\mathrm{d} 625[\mathrm{OH}] \mathrm{D}_{3}\right)$ eluted in methanol and subsequent online solid phase extraction (Recipe, code MS7030). The method was calibrated with ClinCal Serum Calibrators from RECIPE (Munich, Germany) and allow an equimolar detection of the two major 25(OH)D species, $25(\mathrm{OH}) \mathrm{D}_{3}$ and $25(\mathrm{OH}) \mathrm{D}_{2}$. According to manufacturer's declaration for $25(\mathrm{OH}) \mathrm{D}_{3}$, the assay is linear between 7.5 and $375 \mathrm{nmol} / \mathrm{L}$, limit of detection(LoD) is $1.7 \mathrm{nmol} / \mathrm{L}$ and limit of quantification (LoQ) is $7.5 \mathrm{nmol} / \mathrm{L}$. For $25(\mathrm{OH}) \mathrm{D}_{2}$, the assay is linear between 3.5 and $605 \mathrm{nmol} / \mathrm{L}, \mathrm{LoD}$ is 1.0 and $\mathrm{LoQ}$ is $3.5 \mathrm{nmol} / \mathrm{L}$. Imprecision is $<8.8 \%$ and $<8.7$ for $25(\mathrm{OH}) \mathrm{D}_{3}$ and $25(\mathrm{OH}) \mathrm{D}_{2}$, respectively. In our laboratory, the long-term total imprecision was $<7.3 \%$ at high and low levels. For statistical 
purposes, samples below the LoQ have been assigned a value of $3.75 \mathrm{nmol} / \mathrm{L}$, which is half way between 0 and $7.5 \mathrm{nmol} / \mathrm{L}$.

PTH was measured in lithium-heparin plasma using the PTH STAT assay from Roche Diagnostics (Mannheim, Germany) on a Cobas 8000 auto-analyzer. Total imprecision was 3.8 and $2.6 \%$ at concentrations of 13.6 and $361.3 \mathrm{pg} / \mathrm{mL}$, respectively. The reference range provided in the manufacturers package insert is $15-65 \mathrm{pg} / \mathrm{mL}$.

\section{Statistical analysis}

We calculated the following descriptive statistics: mean, median 2.5 th, 5th 95 th 97.5 th percentile for total $25(\mathrm{OH})$ $\mathrm{D}, 25(\mathrm{OH}) \mathrm{D}_{3}$ and $25(\mathrm{OH}) \mathrm{D}_{2}$. Subgroups were formed on the base of gender, age, season and serum PTH. Differences between groups were explored using the Mann-Whitney (2 groups) or the Kruskal-Wallis ( $>2$ groups) test. A $p$ value of $<0.01$ was considered significant. For post hoc analysis, a Wilcoxon test was used.

Seasonal variation was explored using the reference limit estimator (version 17.10.2015) developed by the German Society of Clinical Chemistry and Laboratory Medicine (DGKL), based on $\mathrm{R}$ version 3.1.0. In addition, 25(OH)D results were plotted against the date of analysis. A GAM (generalized additive model) model was used to smoothen the median over time and to calculate $95 \%$ CI for it. Using median values per month, a weighted spline-based smoothing function is applied.

Statistical analyses were performed with Microsoft Excel 2010 (Microsoft, Redmond, WA,USA) and Medcalc v17.4.4 software (Belgium).

\section{Results}

\section{General characteristics of the cohort}

From all 74,235 serum 25(OH)D results, 18,811 (25.3\%) were from males and 55,424 (74.7\%) from females. The mean age of all subjects was 59.3 years (range 18-104 years). Serum 25(OH)D was predominantly tested in individuals between 41 and 80 years of age (75.4\%). Subjects between 19 and 40 years accounted for only $14.6 \%$ of all requests. During summer/autumn, the number of requests was lower than in the winter/spring period: 35.316 requests $(47.6 \%)$ vs. 38.919 requests $(52.4 \%)$.

\section{Global serum 25(OH)D status in the South Tyrolean population}

The average $25(\mathrm{OH}) \mathrm{D}$ concentration in the entire cohort was $68.6 \mathrm{nmol} / \mathrm{L}$ (range $7.5-1880 \mathrm{nmol} / \mathrm{L}$ ). The 2.5 th and 97.5th percentile spanned a rather wide range from 12 to $159 \mathrm{nmol} / \mathrm{L}$ (Table 1$)$. In $0.5 \%$ of all samples, $25(\mathrm{OH}) \mathrm{D}$ was below $7.5 \mathrm{nmol} / \mathrm{L}$, the LoQ of our method. Subjects with non-quantifiable $25(\mathrm{OH}) \mathrm{D}$ had a mean age of 68 years and were predominantly females. The prevalence of nonquantifiable $25(\mathrm{OH}) \mathrm{D}$ concentrations increased with age: 19-40 years: $9.5 \%, 41-60: 23.6 \%, 61-80: 32.5 \%$ and $>80$ : $34.4 \%$, respectively. Table 2 shows vitamin $\mathrm{D}$ distribution according to different $25(\mathrm{OH}) \mathrm{D}$ cut-off levels.

\section{Prevalence of measurable serum 25(OH) $\mathrm{D}_{2}$ in the South Tyrolean population}

In 620 samples, $25(\mathrm{OH}) \mathrm{D}_{2}$ was detected in quantifiable concentrations. This accounts for $0.84 \%$ of the entire cohort. In subjects between 61 and 80 years, $25(\mathrm{OH}) \mathrm{D}_{2}$ was found most frequently. The average concentration in males and females was 13.5 and $17.0 \mathrm{nmol} / \mathrm{L}$, respectively, and did not change with age (differences between age groups were not significant, supplementary table 1).

\section{Differences in serum 25(OH)D status based on age and gender}

In males, the $25(\mathrm{OH}) \mathrm{D}$ concentration was significantly lower than in females (median 60 vs. $67 \mathrm{nmol} / \mathrm{L}, p<0.001$ ). Although there was a median difference of $7 \mathrm{nmol} / \mathrm{L}$ between males and females, the 2.5th and 97.5th percentiles were rather similar (Table 1 ). Figure 1 shows the frequency distribution of total $25(\mathrm{OH}) \mathrm{D}$ results in males and females. The classification of $25(\mathrm{OH}) \mathrm{D}$ results according to the functional categories suggested by the Endocrine Society and the proportion of $25(\mathrm{OH}) \mathrm{D}$ categories by age group is shown in Fig. 2.

The mean total $25(\mathrm{OH}) \mathrm{D}$ concentration was lowest in males older than 80 years (Table 1). Amongst women, the average $25(\mathrm{OH}) \mathrm{D}$ concentration increased with age. Although men also showed significant differences between age groups no clear trend could be observed. An adequate total $25(\mathrm{OH}) \mathrm{D}$ concentration $(>76 \mathrm{nmol} / \mathrm{L})$ was most frequently found in individuals aged $61-80$ years $(43.5 \%$ of all women and $30.6 \%$ of all men). Severe $25(\mathrm{OH}) \mathrm{D}$ deficiency $(<25 \mathrm{nmol} / \mathrm{L})$ was most common in subjects older than 80 years $(19.7 \%$ of all men and $17 \%$ of all women in this age group).

\section{Total 25(OH)D status in subjects with normal PTH}

Out of 74,235 samples, we identified 3801 cases where PTH was requested at the same occasion. The origin of these requests was widespread and not attributable to a specific doctor or discipline. From these cases, 2,313 showed a normal PTH and thus were included in the analysis. In subjects with normal PTH, the mean serum 25(OH)D concentration was $11 \mathrm{nmol} / \mathrm{L}$ higher than in the entire cohort (80 


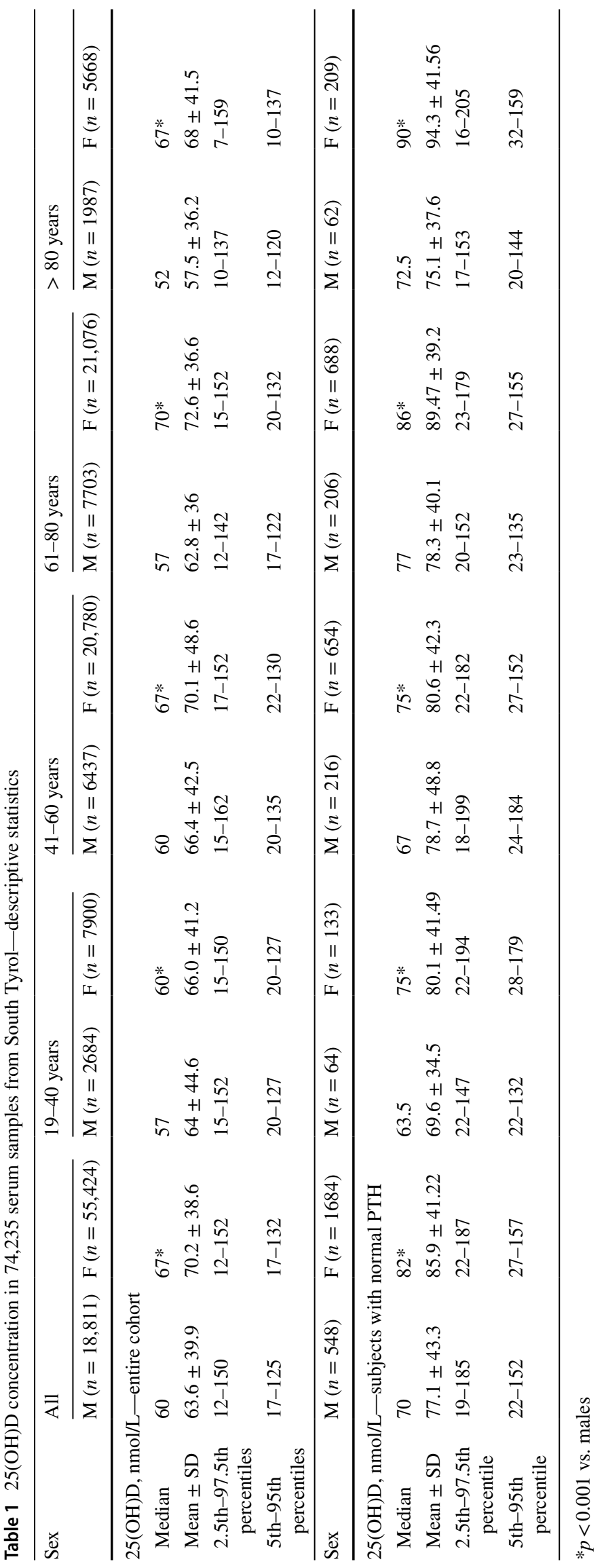



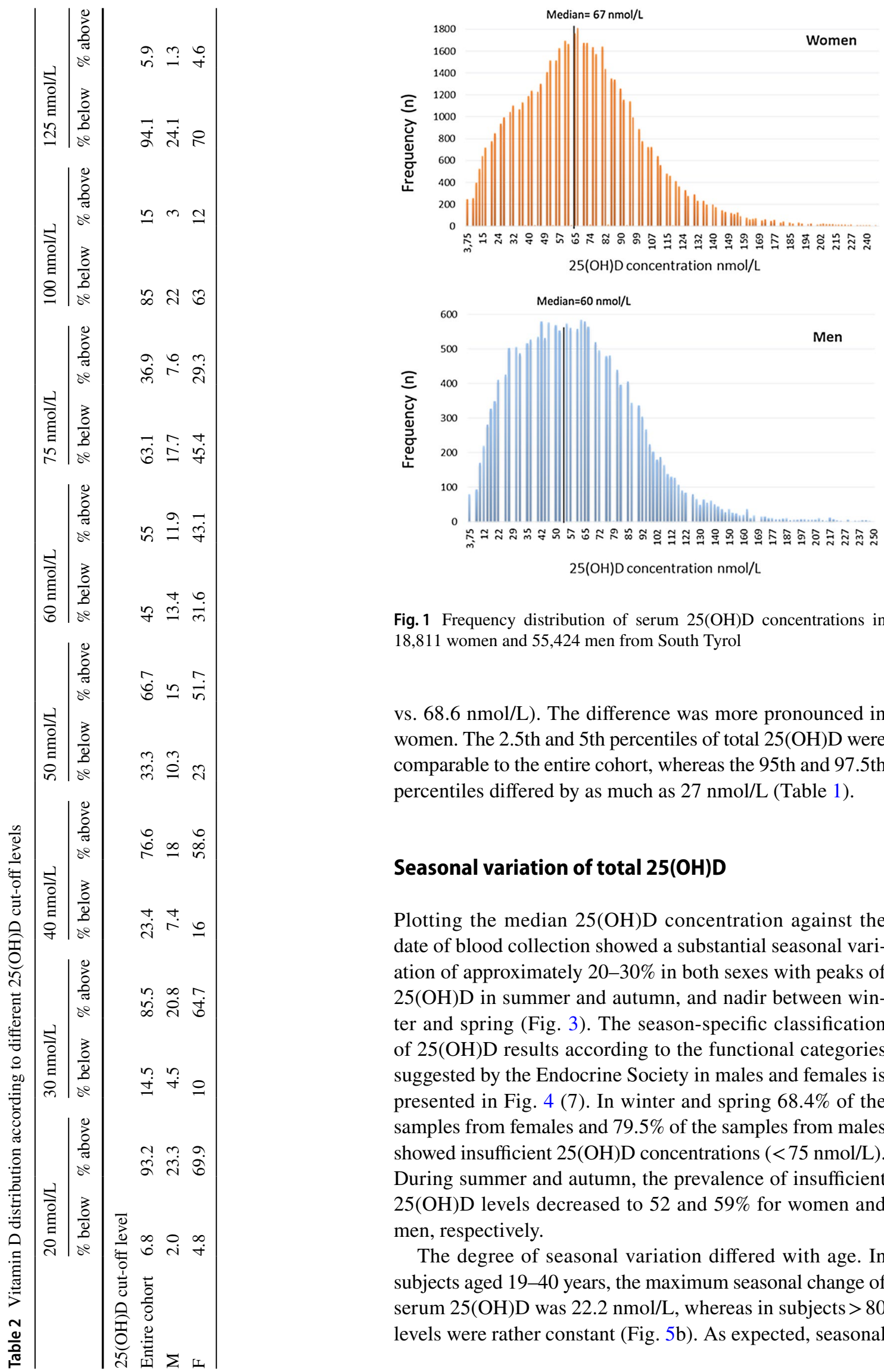

Fig. 1 Frequency distribution of serum 25(OH)D concentrations in 18,811 women and 55,424 men from South Tyrol

vs. $68.6 \mathrm{nmol} / \mathrm{L}$ ). The difference was more pronounced in women. The 2.5 th and 5 th percentiles of total $25(\mathrm{OH}) \mathrm{D}$ were comparable to the entire cohort, whereas the 95th and 97.5th percentiles differed by as much as $27 \mathrm{nmol} / \mathrm{L}$ (Table 1).

\section{Seasonal variation of total 25(OH)D}

Plotting the median 25(OH)D concentration against the date of blood collection showed a substantial seasonal variation of approximately $20-30 \%$ in both sexes with peaks of $25(\mathrm{OH}) \mathrm{D}$ in summer and autumn, and nadir between winter and spring (Fig. 3). The season-specific classification of $25(\mathrm{OH}) \mathrm{D}$ results according to the functional categories suggested by the Endocrine Society in males and females is presented in Fig. 4 (7). In winter and spring $68.4 \%$ of the samples from females and $79.5 \%$ of the samples from males showed insufficient $25(\mathrm{OH}) \mathrm{D}$ concentrations $(<75 \mathrm{nmol} / \mathrm{L})$. During summer and autumn, the prevalence of insufficient 25(OH)D levels decreased to 52 and $59 \%$ for women and men, respectively.

The degree of seasonal variation differed with age. In subjects aged 19-40 years, the maximum seasonal change of serum $25(\mathrm{OH}) \mathrm{D}$ was $22.2 \mathrm{nmol} / \mathrm{L}$, whereas in subjects $>80$ levels were rather constant (Fig. 5b). As expected, seasonal 


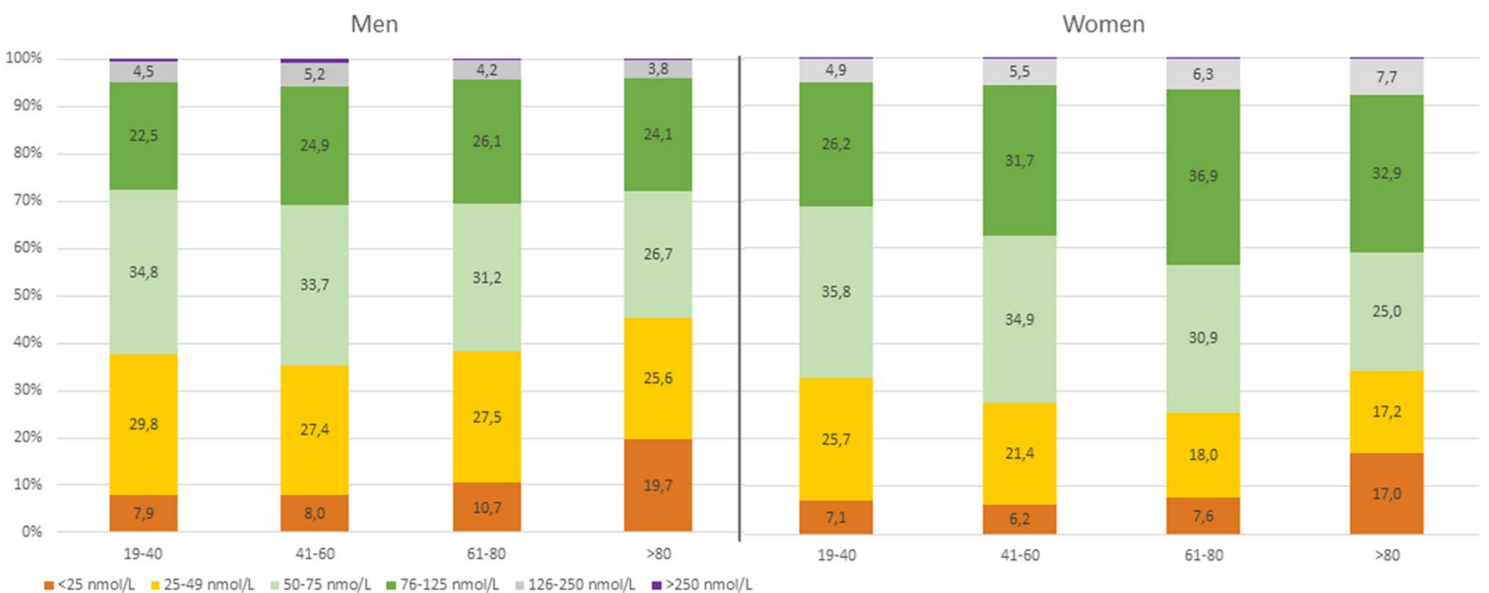

Fig. 2 Distribution of serum 25(OH)D concentrations in males and females of different age groups according to the categories recommended by the guidelines of the Endocrine Society Guideline
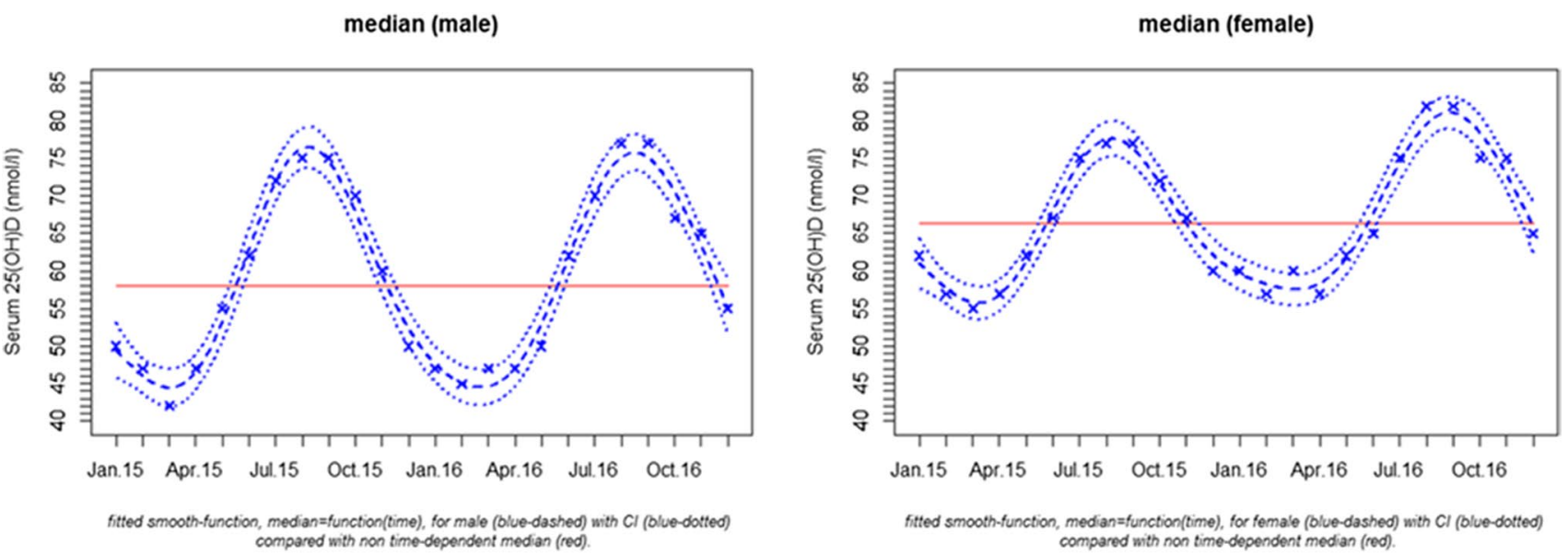

Fig. 3 Circannual variation of the median (dashed line) and its 95\% confidence interval (dotted line) of serum 25(OH)D in males and females $>18$ years of age. A GAM model was used to smoothen the median and to calculate $95 \%$ CIs
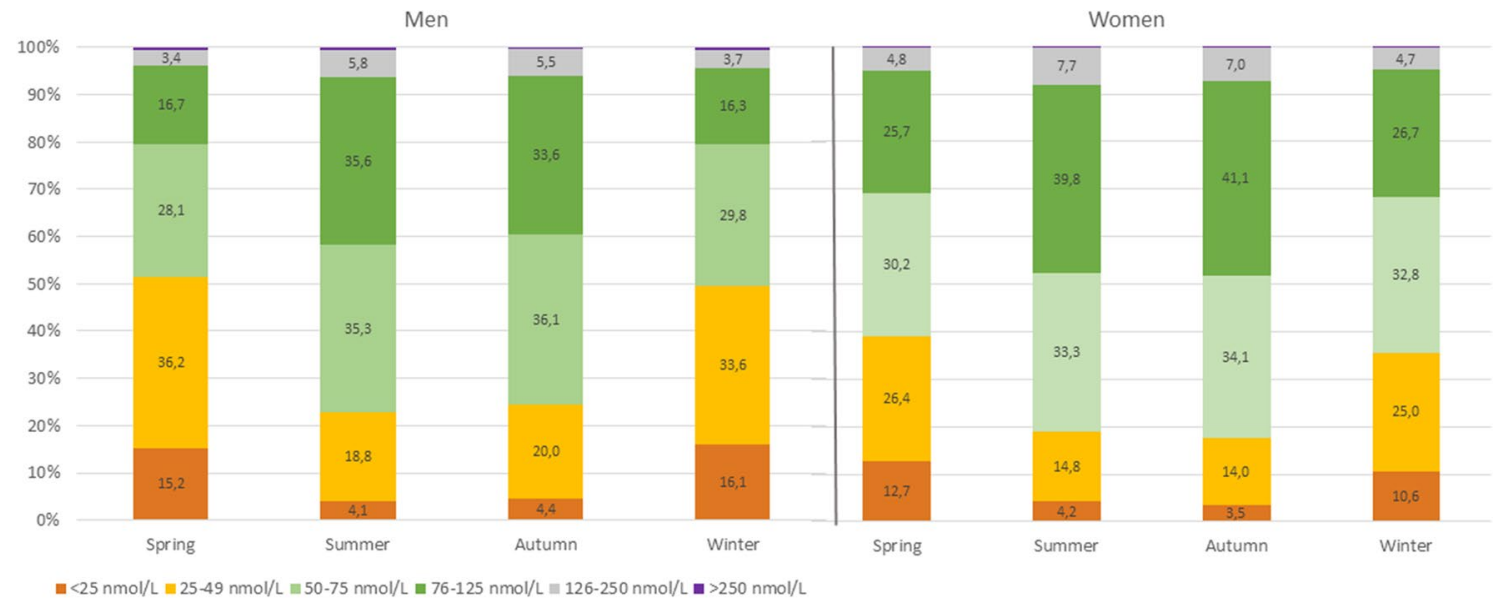

Fig. 4 Seasonal distribution of serum $25(\mathrm{OH}) \mathrm{D}$ concentrations in males and females according to the categories recommended by the guidelines of the Endocrine Society Guideline 
variation was observed for total $25(\mathrm{OH}) \mathrm{D}$ concentration, but not for $25(\mathrm{OH}) \mathrm{D}_{2}$ (Fig. 5a).

\section{Discussion}

In South Tyrol, 25(OH)D is measured most frequently in women aged $61-80$ years. The average concentration is $68.6 \mathrm{nmol} / \mathrm{L}$ with females having higher levels than males. The prevalence of vitamin D deficiency depends on season and gender, but is highest amongst subjects $>80$ years of age during winter and spring. $25(\mathrm{OH}) \mathrm{D}_{2}$ is measurable in $0.84 \%$ of all samples with an average concentration of $17 \mathrm{nmol} / \mathrm{L}$.

The high number of requests in females is supposedly due to an increased awareness of the health issues related to vitamin D deficiency and a more frequent use of supplements. A similar requesting pattern has been reported in the UK [23]. The average 25(OH)D concentration in South Tyrol is close to the sufficiency level and substantially higher than in other European cohorts [24-27]. These differences can be explained by the composition of the study cohorts, the amount of sun exposure, the season of blood collection and the analytical methods used. For example, in 8151 adult Germans, a mean serum 25(OH)D concentration of $45.6 \mathrm{nmol} / \mathrm{L}$ was found [28]. This cohort was substantially younger than ours and lived at a latitude between $50^{\circ}$ and $51^{\circ}$ with approximately $1500 \mathrm{~h}$ of sunshine per year. In contrast, South Tyrol is located in the Southern Alps at a latitude

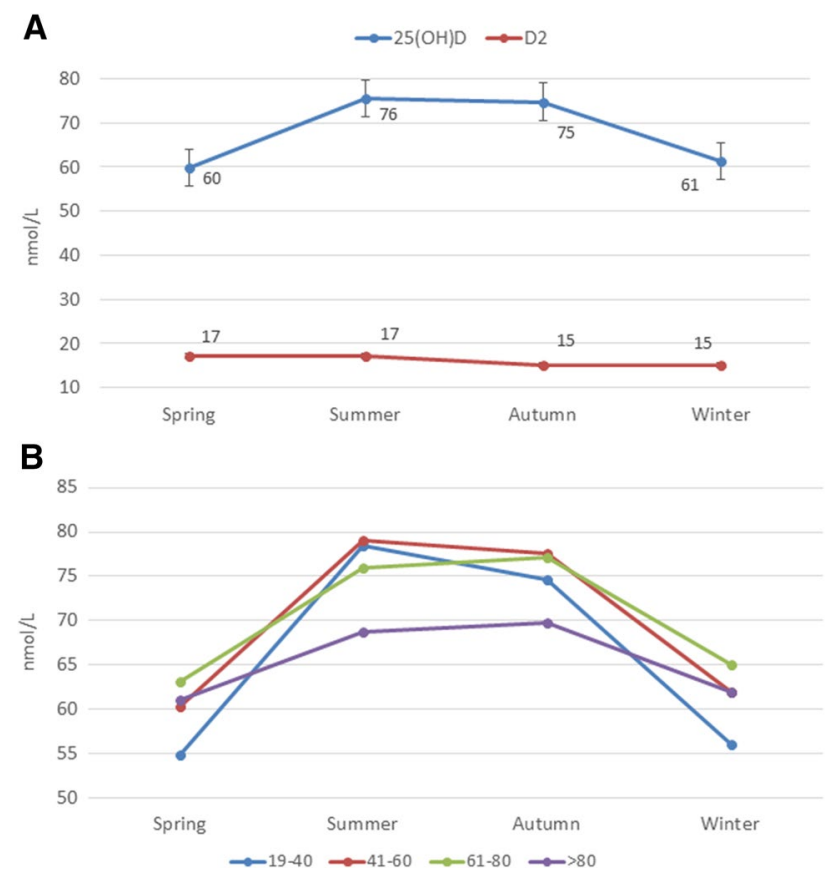

Fig. 5 a Seasonal variation of mean total serum 25(OH)D and $25(\mathrm{OH}) \mathrm{D}_{2}$. b Seasonal variation of mean total serum $25(\mathrm{OH}) \mathrm{D}$ in different age group of $46^{\circ}$ and $47^{\circ}$ and has approximately $2000 \mathrm{~h}$ of sunshine per year [29]. Furthermore, South Tyrol is a mountainous region with many people living at an altitude between 1000 and $1500 \mathrm{~m}$ above sea level where UVB radiation is more intense due to a lower absorption in the atmosphere [30]. In most previous studies, serum $25(\mathrm{OH}) \mathrm{D}$ was measured by immunoassays, which may differ systematically in their analytical performance from the NIST 972a aligned LC-MS/ MS method used here.

On average South Tyrolean women show a $7 \mathrm{nmol} / \mathrm{L}$ higher $25(\mathrm{OH}) \mathrm{D}$ concentration than males. Schleicher et al. also observed $4 \mathrm{nmol} / \mathrm{L}$ higher $25(\mathrm{OH}) \mathrm{D}$ concentrations in white American women than in men [31]. In contrast, other studies showed higher levels in males $[9,21]$ or no gender difference $[28,32]$. These discrepancies might be caused by differences in life style, such as time spent outdoor, clothing and the use of supplements. It can be speculated that differences between males and females are population-specific and there may not be a systemic difference.

$25(\mathrm{OH}) \mathrm{D}_{2}$ represents a major interference in immunoassays $[17,18]$. Our results demonstrate a very low prevalence of quantifiable amounts of $25(\mathrm{OH}) \mathrm{D}_{2}$, which is much lower than in France, China and the USA, where vitamin $\mathrm{D}_{2}$-containing supplements are frequently used [33]. As in most European countries, vitamin D supplements in Italy contain vitamin $\mathrm{D}_{3}$ this difference is not unexpected [33]. Cashman et al. reported age and vitamin D supplementation as positive predictors of $25(\mathrm{OH}) \mathrm{D}_{2}$ [20]. Considering that many immunoassays do not detect $25(\mathrm{OH}) \mathrm{D}_{2}$ and $25(\mathrm{OH})$ $\mathrm{D}_{3}$ in equimolar fashion laboratories should account for the local prevalence of quantifiable concentrations of $25(\mathrm{OH}) \mathrm{D}_{2}$ when choosing their method.

The average PTH concentration decreased continuously across classes of rising $25(\mathrm{OH}) \mathrm{D}$ concentrations from $122 \mathrm{pg} / \mathrm{mL}(25(\mathrm{OH}) \mathrm{D}:<25 \mathrm{nmol} / \mathrm{L})$ to $49 \mathrm{pg} / \mathrm{mL}(25(\mathrm{OH})$ $\mathrm{D}:>250 \mathrm{nmol} / \mathrm{L})$. Interestingly, none of the patients with a serum $25(\mathrm{OH}) \mathrm{D}$ concentration $>250 \mathrm{nmol} / \mathrm{L}$ showed a suppressed PTH. In subjects with normal PTH, average $25(\mathrm{OH}) \mathrm{D}$ was $11 \mathrm{nmol} / \mathrm{L}$ higher than in the entire cohort, which alludes to a suboptimal supply with vitamin D in a relevant fraction of our cohort. In 507 subjects, serum calcium measurements were also available. Serum calcium was comparable in subjects with $25(\mathrm{OH}) \mathrm{D}$ concentrations $<25 \mathrm{nmol} / \mathrm{L}$ (average $2.35[1.75-2.84] \mathrm{mmol} / \mathrm{L}$ ) and $>250 \mathrm{nmol} / \mathrm{L}(2.38[1.56-2.89] \mathrm{mmol} / \mathrm{L})$. This suggests that the majority of subjects is able to maintain calcium/phosphate homeostasis across a wide range of $25(\mathrm{OH}) \mathrm{D}$ concentrations. Furthermore, hypercalcemia does not appear to be a common problem in the presence of excess $25(\mathrm{OH})$ D concentrations. The lack of clinical information in our cohort precludes an additional evaluation of bone and mineral metabolism. Nevertheless, our results are in agreement with previous studies showing a wide range of $25(\mathrm{OH}) \mathrm{D}$ 
concentrations in different populations with the 5th percentile at approximately $\leq 20 \mathrm{nmol} / \mathrm{L}$. However, in other studies, the 5th percentile was substantially higher [20]. However, all these studies have measured 25(OH)D by immunoassay. At low concentrations, these assays can deviate by more than $10 \mathrm{nmol} / \mathrm{L}$ from NIST 972a aligned LC-MS/MS methods $[17,20]$. The limited accuracy of immunoassays is mainly due to different efficacies when separating $25(\mathrm{OH}) \mathrm{D}$ from VDBP and other carriers. $25(\mathrm{OH}) \mathrm{D}_{2}$ and heterophile antibodies are additional interfering factors that can cause inaccuracies $[17,18]$. Besides analytical issues, strong regional variations of serum 25(OH)D have also been described [26], which are in large parts driven by variable UV-B exposure, skin color, genetical differences (VDBP) and vitamin D supplementation.

The prevalence of vitamin D deficiency depends on the cut-off used and the season of blood collection. During summer/autumn, $23 \%$ of males and $18 \%$ of females have deficient $25(\mathrm{OH}) \mathrm{D}$ concentrations $(<50 \mathrm{nmol} / \mathrm{L})$. This increases by approximately $40-50 \%$ during winter and spring. Previous studies from Italy and other European countries reported a substantially higher prevalence of vitamin D deficiency ranging from 18.6 to $76.1 \%$ [20]. In addition, the percentage of results in the adequate range $>75 \mathrm{nmol} / \mathrm{L}$ is considerably higher in South Tyrol than in other regions. The high degree of sun exposure is probably a major driver of the rather good $25(\mathrm{OH}) \mathrm{D}$ status in South Tyrol. However, analytical issues may also have contributed to these differences.

Variable exposure to UV-B irradiation throughout the year strongly influences circulating $25(\mathrm{OH}) \mathrm{D}$ concentrations. In the present study, seasonal variation of serum $25(\mathrm{OH}) \mathrm{D}$ was $20 \mathrm{nmol} / \mathrm{L}$ in males and $15 \mathrm{nmol} / \mathrm{L}$ in females. With increasing age the seasonal variation of $25(\mathrm{OH}) \mathrm{D}$ decreases and disappears almost completely in individuals $>80$ years. This phenomenon can probably be explained by more sun exposure in younger individuals when compared to older subjects who live predominantly indoor and wear long clothes. In addition, aged skin is less effective in synthesizing vitamin $\mathrm{D}_{3}$ [34]. However, seasonal variation of 25(OH)D differs substantially between studies [35-37]. $25(\mathrm{OH}) \mathrm{D}_{2}$, representing predominantly oral intake, varies little throughout the year.

Despite a large number of measurements, the present results are limited by an unknown number of repeat analyses in our cohort. In addition, the present cohort includes some vitamin D-supplemented subjects and individuals with renal impairment. However, the very large number of samples most likely compensates these shortcomings. Strict quality control standards and successful participation in an external quality assurance program where target values are aligned to the reference method lend particular strength to our results. Other epidemiologic studies from the USA, Norway and Netherlands that measured 25(OH)D by NIST 972a aligned LC-MS/MS methods found comparable 25(OH)D concentrations [20,31].

In conclusion, average serum 25(OH)D in South Tyrol is higher than in other European cohorts. The majority of subjects is able to maintain normal calcium and PTH concentrations across a wide range of $25(\mathrm{OH}) \mathrm{D}$ concentrations. Seasonal variation is an important aspect in young and middle-aged adults, but becomes less relevant in elderly subjects. $25(\mathrm{OH}) \mathrm{D}_{2}$ is of minor practical importance in South Tyrol.

Acknowledgements Open access funding provided by Medical University of Graz. Markus Herrmann conceived the study design and did the major contribution in paper writing. He had primary responsibility for final content. Silvia Giuliani, Verena Barbieri and Angela Maria Di Pierro analysed data, performed statistical analysis provided tables and figures. All authors discussed the results and commented on the manuscript. All authors approved submission.

\section{Compliance with ethical standards}

Conflict of interest On behalf of all authors, the corresponding author states that there is no conflict of interest.

Ethical approval Study approved by the local ethical committee (No. 0055719-BZ).

Open Access This article is distributed under the terms of the Creative Commons Attribution 4.0 International License (http://creativeco mmons.org/licenses/by/4.0/), which permits unrestricted use, distribution, and reproduction in any medium, provided you give appropriate credit to the original author(s) and the source, provide a link to the Creative Commons license, and indicate if changes were made.

\section{References}

1. Giovannucci E, Liu Y, Rimm EB, Hollis BW, Fuchs CS, Stampfer MJ, Willett WC (2006) Prospective study of predictors of vitamin D status and cancer incidence and mortality in men. Natl Cancer Inst 9:451-459. https://doi.org/10.1093/jnci/djj101

2. Mitri J, Muraru MD, Pittas AG (2011) Vitamin D and type 2 diabetes: a systematic review. Eur J Clin Nutr 65:1005-1015. https ://doi.org/10.1038/ejen.2011.118

3. Pittas AG, Lau J, Hu FB, Dawson-Hughes B (2007) The role of vitamin $\mathrm{D}$ and calcium in type 2 diabetes. A systematic review and meta-analysis. J Clin Endocrinol Metab 92:2017-2029. https ://doi.org/10.1210/jc.2007-0298

4. Visser M, Deeg DJ, Lips P, Longitudinal Aging Study Amsterdam (2003) Low vitamin D and high parathyroid hormone levels as determinants of loss of muscle strength and muscle mass (sarcopenia): the Longitudinal Aging Study Amsterdam. J Clin Endocrinol Metab 88:5766-5772. https://doi.org/10.1210/jc.2003-030604

5. Herrmann M, Sullivan DR, Veillard AS, McCorquodale T, Straub IR, Scott R, Laakso M, Topliss D, Jenkins AJ, Blankenberg S, Burton A, Keech AC, FIELD Study Investigators (2015) Serum 25-hydroxyvitamin D: a predictor of macrovascular and microvascular complications in patients with type 2 diabetes. Diabetes Care 38:521-528. https://doi.org/10.2337/dc14-0180 
6. Agmon-Levin N, Theodor E, Segal RM, Shoenfeld Y (2013) Vitamin D in systemic and organ-specific autoimmune diseases. Clin Rev Allergy Immunol 45:256-266. https://doi.org/10.1007/s1201 6-012-8342-y

7. Holick MF, Binkley NC, Bischoff-Ferrari HA, Gordon CM, Hanley DA, Heaney RP, Murad MH, Weaver CM, Endocrine Society (2011) Evaluation, treatment, and prevention of vitamin D deficiency: an endocrine society clinical practice guideline. J Clin Endocrinol Metab 96:1911-1930. https://doi.org/10.1210/ jc.2011-0385

8. Ross AC, Manson JE, Abrams SA, Aloia JF, Brannon PM, Clinton SK, Durazo-Arvizu RA, Gallagher JC et al (2011) The 2011 report on dietary reference intakes for calcium and vitamin $\mathrm{D}$ from the Institute of Medicine: what clinicians need to know. J Clin Endocrinol Metab 96(1):53-58

9. Aloia JF The (2011) Report on dietary reference intake for vitamin D: where do we go from here? J Clin Endocrinol Metab 96(10):2987-2996. https://doi.org/10.1210/jc.2011-0090

10. Ross AC, Taylor CR, Yaktine AL, Del Valle HB (2011) Committee to review dietary reference intakes for vitamin $\mathrm{D}$ and calcium and institute of medicine, dietary reference intakes for calcium and vitamin D. The National Academy Press (US), Washington DC

11. Soares L, Pedrosa W. Elói-Santos SM, Vasconcellos LS (2017) 25-Hydroxyvitamin D threshold values should be age-specific. Clin Chem Lab Med 55(7):e140-e142. https://doi.org/10.1515/ cclm-2016-0798

12. Yetley EA (2008) Assessing the vitamin D status of the US population. Am J Clin Nutr 88:558S-564S. https://doi.org/10.1093/ ajen/88.2.558S

13. Powe CE, Karumanchi SA, Thadhani (2014) Vitamin D-binding protein and vitamin D in blacks and whites. N Engl J Med 370:880-881. https://doi.org/10.1056/NEJMc1315850

14. Berg AH, Powe CE, Evans MK, Wenger J, Ortiz G, Zonderman AB, Suntharalingam P, Lucchesi K, Powe NR, Karumanchi SA, Thadhani RI (2015) 24,25-Dihydroxyvitamin d3 and vitamin D status of community-dwelling black and white Americans. Clin Chem 61:877-884. https://doi.org/10.1373/clinchem.2015.24005 1

15. Valcour A, Blocki F, Hawkins DM, Rao SD (2012) Effects of age and serum 25-OH-vitamin D on serum parathyroid hormone levels. J Clin Endocrinol Metab 97:3989-3995. https://doi. org/10.1210/jc.2012-2276

16. Farrell CJ, Martin S, McWhinney B, Straub I, Williams P, Herrmann M (2012) State-of-the-art vitamin D assays: a comparison of automated immunoassays with liquid chromatography-tandem mass spectrometry methods. Clin Chem 58:531-542. https://doi. org/10.1373/clinchem.2011.172155

17. Farrell C, Soldo J, Williams P, Herrmann M (2012) 25-Hydroxyvitamin $\mathrm{D}$ testing: challenging the performance of current automated immunoassays. Clin Chem Lab Med 50:1953-1963. https ://doi.org/10.1515/cclm-2012-0522

18. Cavalier E, Wallace AM, Carlisi A, Chapelle JP, Delanaye P, Souberbielle JC (2011) Cross-reactivity of 25-hydroxy vitamin D2 from different commercial immunoassays for 25-hydroxy vitamin D: an evaluation without spiked samples. Clin Chem Lab Med 49:555-558. https://doi.org/10.1515/CCLM.2011.072

19. Woitge HW, Knothe A, Witte K, Schmidt-Gayk H, Ziegler R, Lemmer B, Seibel MJ (2000) Circannual rhythms and interactions of vitamin D metabolites, parathyroid hormone, and biochemical markers of skeletal homeostasis: a prospective study. J Bone Miner Res 15:2443-2450. https://doi.org/10.1359/ jbmr.2000.15.12.2443

20. Cashman KD, Dowling KG, Škrabáková Z, Gonzalez-Gross M, Valtueña J, De Henauw S, Moreno L, Damsgaard CT et al (2016)
Vitamin D deficiency in Europe: pandemic? Am J Clin Nutr 103(4):1033-1044. https://doi.org/10.3945/ajcn.115.120873

21. Tai SS, Bedner M, Phinney KW (2010) Development of a candidate reference measurement procedure for the determination of 25-hydroxyvitamin D3 and 25-hydroxyvitamin D2 in human serum using isotope-dilution liquid chromatography-tandem mass spectrometry. Anal Chem 82:1942-1948. https://doi.org/10.1021/ ac9026862

22. Binkley N, Sempos CT (2014) Vitamin D standardization program (VDSP). standardizing vitamin D assays: the way forward. J Bone Miner Res 29:1709-1714. https://doi.org/10.1002/jbmr.2252

23. Zhao S, Gardner K, Taylor W, Marks E, Goodson N (2015) Vitamin D assessment in primary care: changing patterns of testing. Lond J Prim Care (Abingdon) 7:15-22 (PMC4494470)

24. Carnevale V, Modoni S, Pileri M, Di Giorgio A, Chiodini I, Minisola S, Vieth R, Scillitani A (2001) Longitudinal evaluation of vitamin $\mathrm{D}$ status in healthy subjects from southern Italy: seasonal and gender differences. Osteoporos Int 12:1026-1030. https://doi. org/10.1007/s001980170012

25. Adami S, Romagnoli E, Carnevale V, Scillitani A, Giusti A, Rossini M, Gatti D, Nuti R, Minisola S, Italian Society for Osteoporosis, Mineral Metabolism and Bone Diseases (SIOMMMS) (2011) Guidelines on prevention and treatment of vitamin D deficiency. Italian Society for Osteoporosis, Mineral Metabolism and Bone Diseases (SIOMMMS). Reumatismo 63:129-147. https://doi. org/10.4081/reumatismo.2011.129

26. Hilger J, Friedel A, Herr R, Rausch T, Roos F, Wahl DA, Pierroz DD, Weber P, Hoffmann K (2014) A systematic review of vitamin D status in populations worldwide. Br J Nutr 111:23-45. https:// doi.org/10.1017/S0007114513001840

27. Spiro A, Buttriss JL (2014) Vitamin D: an overview of vitamin D status and intake in Europe. Nutr Bull 39:322-350. https://doi. org/10.1111/nbu.12108

28. Rabenberg M, Scheidt-Nave C, Busch MA, Rieckmann N, Hintzpeter B, Mensink GB (2015) Vitamin D status among adults in Germany-results from the German Health Interview and Examination Survey for Adults (DEGS1). BMC Public Health 15:641. https://doi.org/10.1186/s12889-015-2016-7

29. http://dati.retecivica.bz.it/it/dataset/irraggiamento-solare-annualemedio-sulle-principali-aree-urbanedellalto-adige-in-wh-m-proge tto

30. Holick MF, Chen TC, Lu Z, Sauter E (2007) Vitamin D and skin physiology: a D-lightful story. J Bone Miner Res 22(Suppl 2):V28-V33. https://doi.org/10.1359/jbmr.07s211

31. Schleicher RL, Sternberg MR, Looker AC, Yetley EA, Lacher DA, Sempos CT, Taylor CL, Durazo-Arvizu RA, Maw KL, ChaudharyWebb M, Johnson CL, Pfeiffer CM (2016) National estimates of serum total 25-hydroxyvitamin D and metabolite concentrations measured by liquid chromatography-tandem mass spectrometry in the US population during 2007-2010. J Nutr 146:1051-1061. https://doi.org/10.3945/jn.115.227728

32. Hintzpeter B, Mensink GB, Thierfelder W, Müller MJ, ScheidtNave C (2008) Vitamin D status and health correlates among German adults. Eur J Clin Nutr 62:1079-1089. https://doi. org/10.1038/sj.ejcn.1602825

33. Armas LA, Hollis BW, Heaney RP (2004) Vitamin D2 is much less effective than vitamin D3 in humans. J Clin Endocrinol Metab 89(11):5387-5391. https://doi.org/10.1210/jc.2004-0360

34. Gennari C (2001) Calcium and vitamin D nutrition and bone disease of the elderly. Public Health Nutrb 4(2B):547-559

35. Jablonski NG, Chaplin G (2018) The roles of vitamin D and cutaneous production in human evolution and health. Int $\mathrm{J}$ Paleopathol S1879-9817(17):30133. https://doi.org/10.1016/j. ijpp.2018.01.005

36. Khoo AL, Koenen HJ, Chai LY, Sweep FC, Netea MG, van der Ven AJ, Joosten I (2012) Seasonal variation in vitamin D3 levels 
is paralleled by changes in the peripheral blood human $\mathrm{T}$ Cell compartment. PLoS One 7:e29250. https://doi.org/10.1371/journ al.pone. 0029250

37. Bose S, Breysse PN, McCormack MC, Hansel NN, Rusher RR, Matsui E, Peng R, Curtin-Brosnan R, Diette GB, Center for
Childhood Asthma in the Urban (2013) Outdoor exposure and vitamin D levels in urban children with asthma. Nutr J 12:81. https ://doi.org/10.1186/1475-2891-12-81 